\title{
Comparison of sorption properties of natural and synthetic takovites, $\mathrm{Ni}_{6} \mathrm{Al}_{2}(\mathrm{OH})_{16} \mathrm{CO}_{3} \cdot 4 \mathrm{H}_{2} \mathrm{O}$
}

ElEonora BUTENKO - Azov Sea State Technical University, University Street 7, 87500 Mariupo Ukraine : e-mail: butenkoeo@rambler.ru

DAvID BISH - Indiana University, 1001E. 10th Street, Bloomington, IN 47405 USA * e-mail: bish@indiana.edu

GaLina ABROSIMOVA - Institute of Solid State Physics RAS, 142432 Chernogolovka, Russia e-mail: gea@issp.ac.ru

AleXey KAPUSTIN - Azov Sea State Technical University, University Street 7, 87500 Mariupol, Ukraine * e-mail: kapustin_a_e@pstu.edu

Received: 16. 12. 2013. - Érkezett: 2013. 12. 16. - http://dx.doi.org/10.14382/epitoanyag-jsbcm.2013.18

\section{Abstract}

Most clay minerals are cation exchangers, but the layered double hydroxides are unique in having anion-exchange properties. Takovite, $\mathrm{Ni}_{6} \mathrm{Al}_{2}(\mathrm{OH})_{16} \mathrm{CO}_{3} \cdot 4 \mathrm{H}_{2} \mathrm{O}$, is a layered double hydroxide that occurs in low-silica weathering environments. Natural and synthetic specimens of takovites were compared using atomic absorption spectroscopy, X-ray powder diffraction, and titration with Hammett indicators. In addition, the sorption of alcoholate-anions was compared and the kinetics of chromate and naphthalene sorption were evaluated. The natural and synthetic specimens of takovite have identical structures, chemical properties, and selectivities for organic and inorganic ions. However, the measured rates of physisorption and anion exchange were distinct, possibly due to variations in crystallite size and shape, leading to different access to internal active sites. Keywords: clay minerals, takovite, sorption

\section{Introduction}

Clay minerals are the most widespread natural inorganic ion-exchangers on the surface of the Earth $[1,2,3]$. Most clay minerals are solid acids, although some, including the layered double hydroxides, have a basic character. Unlike most clay minerals that have a permanent negative charge, making them cation exchangers, the layered double hydroxides have a permanent positive charge, making them anion exchangers. The mineral takovite $\left(\mathrm{Ni}_{6} \mathrm{Al}_{2}(\mathrm{OH})_{16} \mathrm{CO}_{3} \cdot 4 \mathrm{H}_{2} \mathrm{O}\right)$, a layered double hydroxide based on the brucite structure, is an important nickel-containing phase in low-silica weathering deposits. Takovite occurs in karstic bauxites and with minerals such as nepouite, gaspeite, and carrboydite in weathered nickel sulfide deposits $[4,5]$.

Takovite and related minerals in the pyroaurite group have structures in which brucite-like layers carry a net positive charge due to the isomorphous substitution of trivalent for divalent cations (such as $\mathrm{Al}^{+3}$-for- $\mathrm{Ni}^{+2}$ in takovite). Carbonate anions and $\mathrm{H}_{2} \mathrm{O}$ molecules occupy the interlayer region. Previous experiments have shown that acid treatments do not result in destruction of the structure and instead result in anion exchange [5].

The synthetic analogs of takovite, pyroaurite, and hydrotalcite are active heterogeneous catalysts in basic catalytic processes, such as oxialkylation, aldol condensations, etc. [6]. In addition, the naturally occurring anionic clay minerals and their synthetic analogs are widely used as sorbents, catalysts, and catalyst precursors. The compositions of the natural and synthetic materials can be identical, and their chemical and physical properties, including their sorption and catalytic properties, can also be identical. However, substantial differences often
Eleonora Butenko

Works at the Department of Chemical Technology and Engineering, Azov Sea State Technical University. She had BSc in chemistry (2006) and MSc in analytical chemistry (2007) at Donetsk National University, Chemistry Faculty. She had a technician practice at Steel work "Azovstal" (2006). She was technician and later graduate student at Department of Chemical Technology and Engineering, Azov Sea State Technical University (2007). Main fields of interests: processes of physical sorption and anionexchange of organic compounds on LDHs to solve environmental problems.

David Bish BSc (1974), Furman University, PhD (1977), Pennsylvania State University, Postdoctoral fellow (1977-1980), Harvard University. Haydn Murray Chair of Applied Clay Mineralogy, Department of Geological Sciences, Indiana University. Main fields of interests: application of crystal chemical and crystal structural fundamentals to geological, materials, and environmental problems, surface properties of smectites, behavior of fluorine in brick raw materials.

Galina Abrosimova

PhD, Scientific Secretary of the Russian Academy of Sciences Institute of Solid State Physics Laboratory of Structure Research. Main fields of interests: solid state physics, experimental physics, nanomaterials, crystal engineering.

Alexey Kapustin Doctor of Science (chemistry). Graduated at Moscow Mendeleev Chemical Technological Institute (1975-1981). His PhD thesis was "Alcohol Ethoxylation Reactions" (1983). His DSc thesis was "Creation of Basic Heterogeneous Catalysts" (1996). Works at Azov Sea State Technical University. Head of Department of Chemical Technology and Engineering of Azov Sea State Technical University, Mariupol, Ukraine.

exist between the properties of the natural and synthetic layered double hydroxides resulting from compositional and structural heterogeneities related to their modes of origin (natural vs. synthesized). The most important difference between the natural anionic minerals and their synthetic analogs is that the natural anionic clays typically display selectivity towards chiral isomers [7]. Such differences in chiroptical selectivity would not be expected on the basis of our knowledge of the crystal structures of these materials.

\section{Experimental}

To compare the structure, physical-chemical properties, and catalytic activity of natural takovite with its synthetic analog, the latter was obtained by precipitation. This method involved mixing a concentrated $(1 \mathrm{M})$, aqueous solution of $\mathrm{Ni}^{2+}$ and $\mathrm{Al}^{3+}$ nitrate with aqueous sodium hydroxide-carbonate to yield an amorphous gel. At a final $\mathrm{pH}$ of 9-10, the carbonate concentration exceeded the stoichiometric requirements for takovite formation by a factor of approximately three. Following precipitation, the gel was allowed to crystallize in the liquid phase by heating for $24 \mathrm{~h}$ at $65^{\circ} \mathrm{C}$ and was then dried at $125^{\circ} \mathrm{C}$.

Synthetic takovite was characterized by atomic absorption spectroscopy (Saturn-4 atomic absorption spectrophotometer 
with flame atomizer), X-ray powder diffraction (XRD), and titration with Hammett indicators. Confirmation of the structural state of the synthetic materials was done by XRD using a Bruker D8 diffractometer with $\mathrm{Cu} \mathrm{K} \alpha$ radiation and a SolX solid-state detector. In order to investigate the basic properties of natural and synthetic takovites, titration with Hammett indicators was used [8]. A sample of takovite in a small beaker filled with benzene was stirred on a magnetic stirrer. Subsequently, a glass cylinder, divided by a porous separator on which a standard sample was installed was inserted into the beaker. A Hammett indicator was added to the benzene and changes in color were observed on the surface of the standard sample. The following indicators were used: Bromothymol Blue $\left(\mathrm{pK}_{\mathrm{a}}=7.2\right)$, 4-Chlor-2-nitroanilin $\left(\mathrm{pK}_{\mathrm{a}}=17.2\right)$, 4-Chloranilin $\left(\mathrm{pK}_{\mathrm{a}}=26.5\right)$, purchased from Aldrich, and 2,4,6-Trinitroanilin $\left(\mathrm{pK}_{\mathrm{a}}=12.2\right), 2,4$-Dinitroaniline $\left(\mathrm{pK}_{\mathrm{a}}=15.0\right)$, and 4-Nitroanilin $\left(\mathrm{pK}_{\mathrm{a}}=18.4\right)$, all purchased from Fluka. Because the takovites have a blue-green color, a sample of calcined $\mathrm{MgO}$ was used for comparison.

The sorption selectivity of synthetic and natural takovites for different alcoholate-ions was measured using a solution containing the respective sodium alcoholates. Deionized water was used and measurements were done under a nitrogen atmosphere. The total concentration of alcoholates corresponded to the concentration of basic sites in takovites, determined by indicator titration $(\mathrm{E}=0.8 \mathrm{meq} / \mathrm{g})$. A solution in which takovite was suspended was placed on a stirrer and maintained at room temperature for 24 hours. The concentration of remaining alcoholates was then determined using a Chrome- 5 chromatograph.

The kinetics of chromate adsorption was determined using a solution of $0.017 \mathrm{~mol} / 1 \mathrm{~K}_{2} \mathrm{CrO}_{4}$ to which takovite was added in a retort. The solution was mixed on a magnetic mixer and aliquots of the solution were sampled at different intervals (1, 3, 10 min., etc.). This solution was filtered and $\mathrm{CCl}_{3} \mathrm{COOH}$ and a $0.5 \%$ solution of diphenylcarbazide was added and stirred for $10 \mathrm{~min}$. The absorbance of the solution was then measured at $546.1 \mathrm{~nm}$ using a KFK-3 photocolorimeter. Finally, the sorption of naphthalene was evaluated with a Chrome- 5 chromatograph by measuring the concentration of naphthalene remaining in solution after introduction of takovite.

\section{Results and discussion}

Atomic absorption chemical analyses showed the followed composition for the synthetic takovite: $\mathrm{Al}-7.58 \mathrm{~mol} \%$; $\mathrm{NiO}$ - $16.40 \%$; C - $9.47 \mathrm{~mol} \%$; O - $66.55 \%$. The corresponding structural formula based on these chemical analyses is approximately $\left[\mathrm{Ni}_{2} \mathrm{Al}(\mathrm{OH})_{6}\right] \mathrm{CO}_{3}$.

The XRD pattern of synthetic takovite in Fig. 1 is consistent with the three-layer rhombohedral structure, with $\mathrm{R}-3 \mathrm{~m}$ space group and unit-cell parameters: $\mathrm{a}=3.025 \AA$, $\mathrm{c}=22.595 \AA$. The positions of the reflections corresponding to a natural takovite are indicated by red lines in the figure, and weak reflections $\left(101-43.6^{\circ}, 104-48.08^{\circ}, 1010-68.92^{\circ}, 0111-73.52^{\circ}, 1013\right.$ $-83.94^{\circ}$ ) were not resolved due to the large peak widths. XRD analysis gave a $\mathrm{d}_{001}$ of $\sim 7.6 \AA$ for both synthetic and natural takovites.

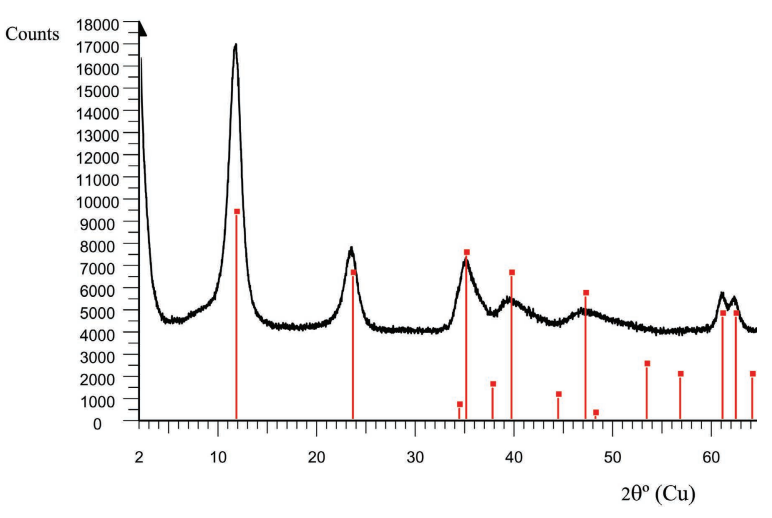

Fig. 1. XRD pattern of synthetic takovite, showing the comparison with ICDD data 15-0087 for a natural takovite (vertical red lines)

1. ábra Szintetikus takovit röntgendiffraktogramja, összehasonlítva az ICDD 15-0087 adatbázisban szereplö természetes takovitéval (függöleges vörös vonalak)

\begin{tabular}{lccc}
$\mathrm{H}_{0}$ & $\mathrm{H}_{0}>\mathbf{7 . 2}$ & $\mathrm{H}_{0}>\mathbf{9 . 3}$ & $\mathbf{H}_{0}>\mathbf{1 2 . 2}$ \\
Natural & 0.79 & 0.30 & 0.01 \\
\hline Synthetic & 0.82 & 0.27 & $\leq 0.01$ \\
\hline
\end{tabular}

Table 1. Concentration of basic sites of different strength on natural and synthetic takovites 1. táblázat A természetes és szintetikus takovitok egyes csoportjainak koncentrációja

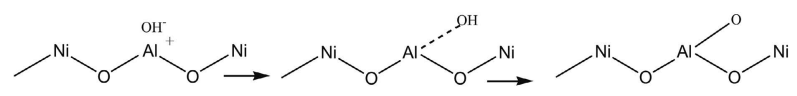

Fig. 2. Transformation of the basic layer structure [6]

2. ábra A rétegszerkezet átalakulása [6]

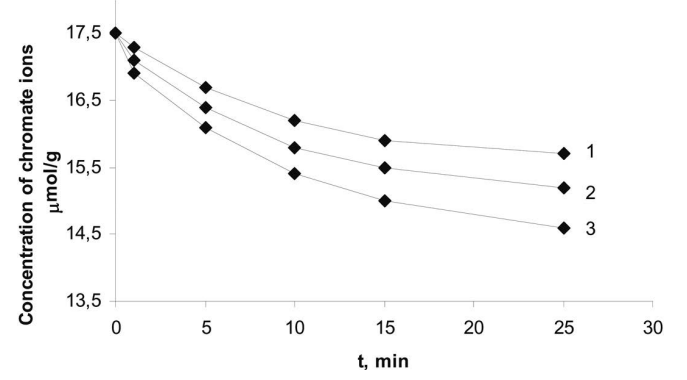

Fig. 3. Adsorption of chromate anions as a function of time for different amounts of natural takovite in suspension $(1-0.05 \mathrm{~g} ; 2-0.07 \mathrm{~g} ; 3-0.1 \mathrm{~g}$ )

3. ábra Kromát anionok adszorpciójának időbeli alakulása különböző összetételü természetes takovit szuszpenziókban (1-0.05g; $2-0.07 g ; 3-0.1 \mathrm{~g})$.

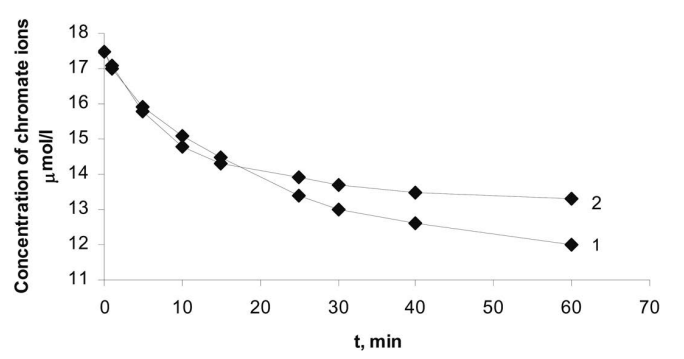

Fig. 4. Sorption of chromate onto synthetic and natural takovite as a function of time (1 - natural takovite; 2 - synthetic takovite)

4. ábra Kromát szorpciójának időbeli alakulása természetes és szintetikus takovit esetén (1 - természetes takovit; 2 - szintetikus takovit)

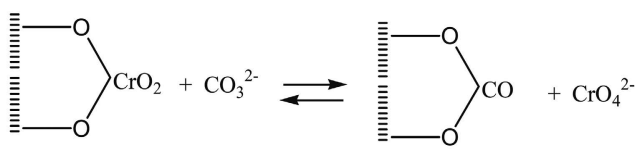

$\mathrm{CO}_{3}^{2-}>\mathrm{NO}_{3}^{-}>\mathrm{CrO}_{4}^{2-}>\mathrm{SO}_{4}^{2-}>\mathrm{HVO}_{4}^{2-}>\mathrm{OH}^{-}>\mathrm{Cl}^{-}>\mathrm{MnO}_{4}$

Fig. 5. The order of preference of synthetic and natural takovites for anions [1] 5. ábra Anionok reakcióképességének sorrendje természetes és szintetikus takovit esetén [1] 


\begin{tabular}{|c|c|c|c|c|c|c|c|c|c|c|c|c|}
\hline \multirow[t]{2}{*}{$\mathbf{T},{ }^{\circ} \mathbf{C}$} & \multicolumn{2}{|c|}{100} & \multicolumn{2}{|c|}{200} & \multicolumn{2}{|c|}{300} & \multicolumn{2}{|c|}{400} & \multicolumn{2}{|c|}{500} & \multicolumn{2}{|c|}{600} \\
\hline & B & $\mathbf{L}$ & B & $\mathbf{L}$ & B & $\mathbf{L}$ & B & $\mathbf{L}$ & B & $\mathbf{L}$ & B & $\mathbf{L}$ \\
\hline Natural & 0.79 & nd & 0.45 & 0.15 & 0.30 & 0.19 & 0.08 & 0.17 & 0.04 & 0.17 & nd & 0.10 \\
\hline Synthetic & 0.82 & nd & 0.55 & 0.01 & 0.31 & 0.14 & 0.13 & 0.22 & 0.03 & 0.20 & nd & 0.12 \\
\hline
\end{tabular}

Table 2. The concentration of basic sites of takovites, $\mathrm{mmol} / \mathrm{g}$ (B - Bronsted, L-Lewis sites; $12.2<H_{0}<17.2$, nd - not detected)

2. táblázat A takovitok egyes csoportjainak koncentrációja, mmol/g (B-Bronsted, L-Lewis; $12.2<H_{0}<17.2$, nd - nem érzékelhetö)

Determination of the acid-base properties of takovites using Hammett indicators of different $\mathrm{pK}_{\mathrm{a}}$ gave the following strength distribution of basic sites (Table 1). These results show that the number of basic sites in synthetic takovite is comparable to that in the natural sample, and the distribution of the strength of basic sites in natural and synthetic takovite is also essentially identical.

Calcining layered double hydroxides causes transformation of the basic layer structure due to dehydration and then dehydroxylation, changing the total basicity and redistributing basic sites on the surface as shown in Fig. 2 [6].

Calcining of takovites at various temperatures up to $600^{\circ} \mathrm{C}$ resulted in the transformation of Bronsted basic sites into Lewis sites (Table 1), which was accompanied by reduction of the total number of sites with a simultaneous increase in the strength of the basic sites, as quantified in Table 2.

Adsorption of chromium anions by synthetic and natural takovite was investigated to understand the anion sorption behavior of these materials. Results of chromate adsorption kinetics experiments for natural takovite are shown in Fig. 3 , showing that the rate of adsorption is proportional to the amount of takovite in suspension (and directly proportional to the concentration of chromate anions in solution). Similar results were obtained for synthetic takovite.

Knowing the concentration of basic sites in takovite ( $\mathrm{E}$ in $\mathrm{mmol} / \mathrm{g}$ ) and the amount of adsorbent, it is possible to calculate the concentration of basic sites in the reaction mixture. As the concentrations of basic sites in synthetic and natural takovites are essentially identical, we anticipated that the sorption processes in these materials would be identical. But Fig. 4 shows that sorption onto synthetic takovite was initially more rapid than onto natural takovite, with natural takovite ultimately taking up more chromate ions. The initial behavior is in agreement with expectations that sorption will be more rapid onto the very fine-grained synthetic takovite. The behavior after about 20 minutes may be related to a larger intrinsic exchange capacity for the natural material.

After completion of the sorption process, the takovites were washed with deionized water and held in water for 48 hours without access to air under a nitrogen atmosphere. Analysis of the liquid phase revealed the absence of chromium ions, demonstrating that desorption did not take place. However, when the takovites were placed in a carbonate-bearing solution, chromate anions were detected, demonstrating the occurrence of anion exchange via the following process:

As previously demonstrated, treatments with various dilute acids and salt solutions do not destroy the crystal structure of takovite. The order of preference of synthetic and natural takovites for anions was obtained from anion-exchange experiments, and natural takovites showed pronounced preference for carbonateions over other anions [5], which is also true for other minerals of the pyroaurite and hydrotalcite groups, see Fig. 5 [1].
In order to differentiate between anion-exchange and physisorption in the adsorption of alcoholate-ions, we conducted additional experiments using alcoholate ions. After conclusion of the sorption process, the takovite powder was extracted from solution, washed in deionized water, dried, and placed in a $1 \%$ aqueous $\mathrm{NaOH}$ solution. Chromatographic analysis of these solutions revealed the presence of alcoholate ions.

The data in Table 3 suggest that the ability of takovite to sorb alcoholate anions diminishes with an increase in the molecular weight of the hydrocarbon radical. This behavior may be explained by an orientation of the hydrocarbon radicals parallel to the basal layers, thereby blocking nearby basic sites. If they were oriented perpendicular to the basal layers, the sorption behavior of all alcoholate ions should be approximately identical. In addition the latter case would lead to an increase in the basal spacing which was not observed.

\begin{tabular}{lccccccc} 
Anions & $\mathbf{C H}_{3} \mathbf{O}$ & $\mathbf{C}_{2} \mathbf{H}_{5} \mathbf{O}$ & $\mathbf{C}_{3} \mathbf{H}_{7} \mathbf{O}$ & $\mathbf{C}_{4} \mathbf{H}_{9} \mathbf{O}$ & $\mathbf{C}_{7} \mathbf{H}_{15} \mathbf{O}$ & $\mathbf{C}_{7} \mathbf{H}_{15} \mathbf{O}$ & $\mathbf{C}_{12} \mathbf{H}_{25} \mathbf{O}$ \\
Natural & 100 & 66 & 37 & 19 & 4 & 1 & $<0.1$ \\
\hline Synthetic & 100 & 70 & 41 & 23 & 8 & 1 & - \\
Table 3. Selectivity of takovites to alcoholate ions (relative units) \\
3. táblázat Takovitok alkoholát ion szelekciója (relatív mérték)
\end{tabular}

X-ray diffraction study revealed that ion-exchange of takovites with nitrate and chloride anions caused only minor changes in the structure with increases in basal spacing [5]. However ion-exchange with sulfate, chromate, and vanadate anions led to considerable change in the basic structure and to formation of two different structures (Table 4).

$\begin{array}{ccccc}\text { Anion } & \mathbf{C O}_{3}{ }^{2-} & \mathbf{S O}_{4}{ }^{2-} & \mathrm{CrO}_{4}{ }^{2-} & \mathrm{HVO}_{4}{ }^{2-} \\ \mathrm{d}_{001}(\AA) & 7.95 & 8.25 & 8.29 & 8.97\end{array}$

Table 4. Basal spacing of takovite with different interlayer anions 4. táblázat Takovitok bázistávolsága különbözö rétegközi anionok esetén

It is interesting to compare the above results for chromate adsorption with the results for absorption of aromatic hydrocarbons of naphthalene by natural and synthetic takovites (Fig. 6).

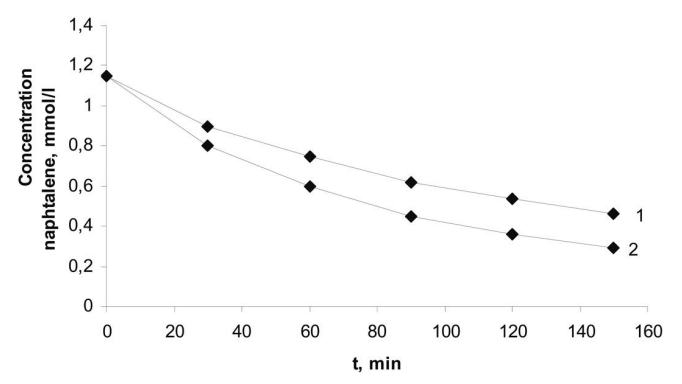

Fig. 6. Sorption of naphthalene on synthetic and natural takovites as a function time (1 - synthetic takovite; 2 - natural takovite)

6. ábra Naftalén szorpciójának időbeli alakulása természetes és szintetikus takovit esetén (1 - szintetikus takovit; 2 -természetes takovit) 
These aromatic hydrocarbons of naphthalene are contained in the interlayer as a result of cooperation of aromatic $\pi$-electrons with the electron orbitals and are physisorbed onto takovite, in contrast to sorption onto layered double hydroxides by anionic compounds such as naphthalene carboxylates or naphthalene nitrates $[9,10]$. The higher activity of natural takovite again is counter to what was expected and may result from the moreordered layer structure and availability of active sites for the sorption of organic compounds.

The physisorption of naphthalene thus contrasts with the anion exchange of chromate, sulfate, and vanadate ions. Data in Fig. 4 and 6 show that natural takovite has a greater capacity for anions and naphthalenes than does the synthetic takovite. These differences could reflect variations in crystal perfection as synthetic takovite is typically considerably more disordered than natural takovite [11]. However, one would normally expect more disordered material to be more effective at chemiand physisorption than a well ordered material with larger crystallite size.

\section{Conclusions}

The results demonstrate that natural and synthetic takovites have similar compositions and structures, identical acid-basic properties, and identical selectivity series. Calcining of takovites transformed Bronsted basic sites into Lewis sites, accompanied by a reduction in the total number of sites and an increase in the strength of the basic sites. However, sorption of anions and naphthalenes occurs at different rates and with different degrees of absorption. It is likely that explanations for differences between the behavior of natural and synthetic takovites lie in differences in their crystallite sizes and degrees of structural order. XRD data demonstrate that the synthetic takovites have very small crystallite sizes and considerable strain, whereas natural takovite occurs in much larger crystallites with little strain. However, based on the XRD results, one would expect synthetic takovite to exhibit more-rapid adsorption kinetics and to have a larger exchange capacity, the opposite of our observations, possibly due to variations in crystallite size and shape, leading to different access to internal active sites.

\section{References}

[1] ASTM 15-0087. JCPDS - International Centre for Diffraction Data.

[2] Bish, D. L. - Brindley, G. W.: A re-investigation of takovite, a Ni-Al hydroxy-carbonate of the pyroaurite group. American Mineralogist, Vol. 62, 458-464. (1977)

[3] Bish, D.: Anion-exchange in takovite: applications to other minerals. Bulletin de Mineralogie, Vol. 103, 170-175. (1980)
[4] Duan, X. - Evans, D. G.: Layered Double Hydroxides. Structure and bonding. D.M.P. Mingos (Ed.). Springer-Verlag. Berlin. Heidelberg. (2006).

[5] Lebedeva, O. V. - Kapustin, A.E.: Problems of indicator titration of basic heterogeneous catalysts. Ukrainian Chemical Journal, Vol. 63, 25-27. (1997)

[6] Kapustin, A.: Inorganic anion-exchangers. Russian Chemistry Reviews, Vol. 60, 1398-1416. (1991)

[7] Kapustin, A.: Catalysis by layered double hydroxides. Scientific problems of modern technology, Vol. 16, 267-275. (2007)

[8] Kapustin, A.: Heterogeneous basic catalysis. Renata. Mariupol (in Russian) (2008)

[9] Putyera, K. - Bandosz, T. J. - Jagieo, J. - Schwarz, J. A.: Effect of template constraints on adsorption properties of synthetic carbons prepared within the gallery of layered double hydroxides. Carbon, Vol. 34, No. 12, 1996, pp. 1559-1567. http://dx.doi.org/10.1016/S0008-6223(96)00112-1 (1996)

[10] Radha, A. V. - Kamath, P. V. - Shivakumara, C.: Order and disorder among the layered double hydroxides: combined Rietveld and DIFFaX approach. Acta Crystallographica Section B, Vol. 63, No. 2, pp. 243-250. http://dx.doi. org/10.1107/S010876810700122X (2007)

[11] Vaccari, A.: Layered double hydroxides: present and future. V. Rives (Ed.). Nova Science Publishers. Inc. New York. (2002)

[12] Zhao, H. - Vance, G. F.: Molecular Inclusion Properties of Hydrophobic Organic Compounds by a Modified $\beta$-Cyclodextrin Intercalated within a Layered Double Hydroxide. Journal of Inclusion Phenomena and Macrocyclic Chemistry, Vol. 31, No. 4, August 1998, pp. 305-317. http:// dx.doi.org/10.1023/A:1007965712719 (1998)

Ref.:

Eleonora Butenko - David Bish - Galina Abrosimova - Alexey Kapustin: Comparison of sorption properties of natural and synthetic takovites, $\mathrm{Ni}_{6} \mathrm{Al}_{2}(\mathrm{OH})_{16} \mathrm{CO}_{3} \cdot 4 \mathrm{H}_{2} \mathrm{O}$ Építőanyag, 65. évf. 4. szám (2013), 97-101. p. http://dx.doi.org/10.14382/epitoanyag-jsbcm.2013.18

Természetes és szintetikus takovitok, $\mathrm{Ni}_{6} \mathrm{Al}_{2}(\mathrm{OH})_{16} \mathrm{CO}_{3} \cdot 4 \mathrm{H}_{2} \mathrm{O}$ szorpciós tulajdonságainak összehasonlítása

A legtöbb agyagásvány kationcserélố tulajdonsággal rendelkezik, azonban a réteges kettôs hidroxidok különleges módon anioncserélố tulajdonságúak. A takovit $\mathrm{Ni}_{6} \mathrm{Al}_{2}(\mathrm{OH})_{16} \mathrm{CO}_{3} \cdot 4 \mathrm{H}_{2} \mathrm{O}$ egy réteges kettôs hidroxid, amely kis szilícium-tartalmú környezetben képződik. A cikkben természetes és szintetikus takovitok összehasonlítása történik atomabszorpciós spektroszkópiával, röntgendiffrakcióval és Hammett indikátoros titrálással. Ezen kívül, alkoholát anionok szorpciójának öszszehasonlítása, illetve kromátok és naftalének szorpciójának kinetikája is bemutatásra kerül. A természetes és szintetikus takovitoknak azonos a szerkezete, a kémiai jellemzôi és a szerves és szervetlen ionszelekciója. Különbség mutatkozott a mért fiziszorpciós sebességben és az anioncserélésben, amely a kristályok eltérô méretébôl és alakjából származhat, amely eltérô mértékében biztosít lehetôséget a belsô aktív részek eléréséhez.

Kulcsszavak: agyagásványok, takovit, szorpció

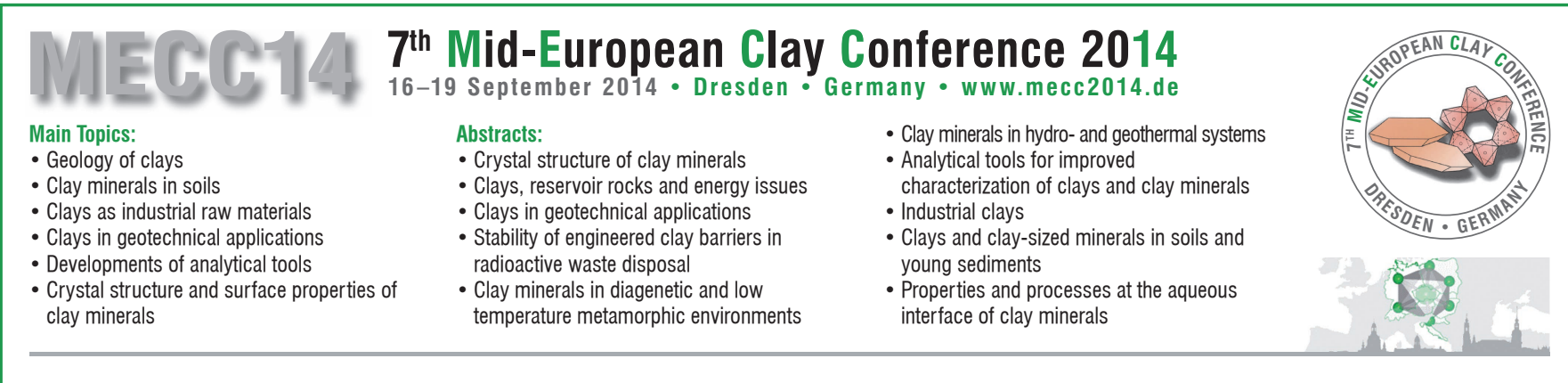

